\title{
Information checking as a form of character management in education
}

\author{
Zulfah Zulfah \\ Magister Pendidikan Kimia, Universitas Negeri Yogyakarta, Indonesia \\ Magister Manajemen Pendidikan Islam, Universitas Islam Negeri Yogyakarta, Indonesia \\ Email: Zulfahzuu@gmail.ac.id \\ Rizka Amalia Shofa \\ Magister Manajemen Pendidikan Islam, Universitas Islam Negeri Yogyakarta, Indonesia \\ Email: Rizkamamalia@gmail.com
}

\begin{abstract}
Research with information checking as a form of character management in education aims to determine the level of curiosity and responsibility of society, in this case, young people to report, to see how they manage the information obtained and disseminated. This research was conducted by survey method. The sampling technique using proportionate stratified random sampling to get a sample from the population in Vocational Health of Sadewa Yogyakarta. Instruments data acquisition using a questionnaire that contained 15 questions covering questions in the curiosity and responsibility for the information obtained. Based on the data obtained, it was found that there is a nursing class score of interest is 134 , and commitment is 98 . While the pharmaceutical grade score of curiosity is 148 , and accountability is 78 . The item of interest looked more significant than the things responsible for the information. Based on the calculation to be obtained percentage nursing class of $65.5 \%$ and pharmaceutical
\end{abstract}


grade amounted to $67.25 \%$. It is certainly still far from the ideals percentage of $100 \%$. So it needs more attention to the cultivation of character the young generation in the era of freedom of information.

Keywords: Checking Information, Curiosity, Responsibility

\section{Introduction}

In this era, one thing that can not be avoided is the widespread dissemination of information that is increasingly difficult to control. Two decades ago, perhaps we still rely on newspapers, television, radio, and other information media. But this day, social media has become a medium of information that is easier to penetrate the community. The intensity of public high enough in using social media to be one of the strong reasons why this phenomenon occurs. According to the latest data from We Are Social, growth of Internet users is also an effect on the growth of social media and mobile users. According to the same report, an active social media users has now reached 2.2 billion, while mobile users reached 3.7 billion (Noviandari, 2015).

The activity level users of social media has become a tool for the management of information media to use social media as one way of marketing news is one of the products. The amount of information published or can be shared to social media certainly provoke the increasing curiosity of the users of social media to information as well as the growing number of information dissemination through social media. The data collected by the Commission I member House of Representatives of the Republic of Indonesia in communications and information technology showed that the distribution of false news shown by a study in early 2016 about the distribution of information about Zika virus.

The study of 200 most popular news shared on Facebook shows that 12 percent of the amount it contains misleading information. Although there were only 12 percent, the most popular news, claiming that "Zika is a hoax", distributed 500 thousand times. On the other hand, a credible videos from the World Health Organization (WHO) only distributed 43 thousand times (Putri, 2017). These data showed a boost community in sharing information on social media is greater than the share it directly from the official website axiomatic.

That phenomenon shows that people are getting accustomed to easily share the information widely without validating the truth. Based on the 
exposure, the authors conducted a study to determine the level of curiosity and responsibility of society in case young generation to information, so that they can see how people manage information gathered and disseminated.

\section{Literature Review}

\section{a. Education of Character Building}

According to the Complete Dictionary of Indonesian, character traits are psychological, behavioral, or character that distinguish one person from another, character, character. Character means to have character, have personality (Kamisa, 1997). Furthermore, the dictionary of psychology stated that the character is a personality in terms of ethical or moral, for example, a person's honesty; usually have connections with relatively fixed properties (Gulo, 1982). Viewed from the standpoint of education, character is an important thing that is considered to have a major role to students, so that the term education of character building.

Education of character building is a conscious and deliberate effort in instilling the values so internalized in self-learners and are reflected in the attitudes and behavior. Education of character building is not just to teach what is right and what is wrong, more than that education of character building inculcate the habit (habituation) about good things so that learners come to understand (the affective domain) good value and usually do (domain behavior). Impact students understanding of the education of character building can be seen from how students are beginning to have better habits and performed continuously (Kemendiknas, 2010).

Education of character building is an effort that was designed and implemented systematically to help students understand the values of human behavior associated with the Almighty God, ourselves, our fellow human beings, the environment, and nationality embodied in thoughts, attitudes, feelings, words, and actions based on religious norms, laws, manners, culture, and customs. According to Ari Gina in Darmiyati Zuhdi, et al. there are seven basic human characters exemplary of the names of God, namely: 1. honest, 2. responsibility, 3. discipline, 4. the visionary, 5. fair. 6. concerned, and 7. Cooperation (Zuhdi, 2008).

While the Josephson Institute of Ethics (2005) via Endang Poerwati categorize six pillars of character, namely 1. trustworthiness, 2. respect, 3 . responsibility, 4. fairness, 5. caring, and 6. citizenship. Still according to Endang 
Poerwati who cite Lewis Barbara A. (2004) suggested the 10 pillars of character, namely: 1 . matter, 2 . be aware of community, 3. to cooperate, 4 . fair, 5 . be willing to forgive, 6. honest, 7. maintain the relationship, 8. respect for others, 9. responsibility, and 10. Safety (Poerwanti, 2011). Aspects of the character or target values that can be integrated in the educational process, among other things: 1 . acts of worship, 2. honesty, 3. responsibility, 4. concern, 5 . cooperation, 6. respect for the person / party, and 7. other values in accordance with religious values, humanist, and nationalism (Darmiyati, 2012).

Education of character building can be done through the stages of knowledge, execution, and habits. Lickona describes the three components in forming good character, namely (Chairiyah, 2011):

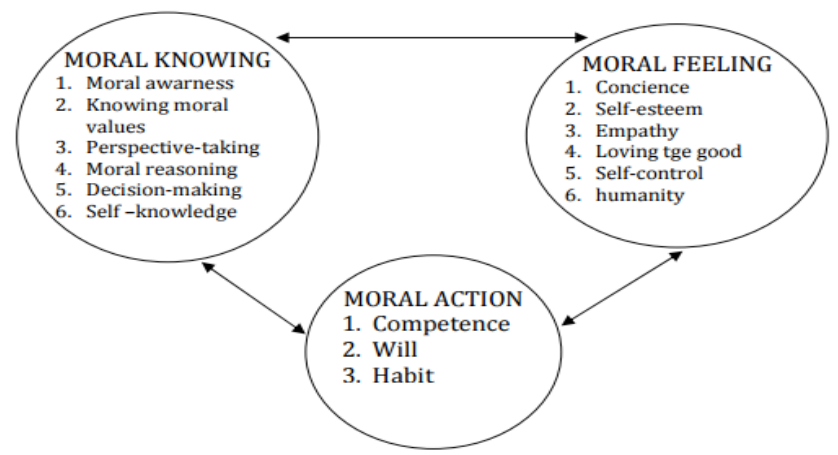

Pict 1. Components of Good Character (Lickona, 1991)

The values of education of character building that is sourced from religion, Pancasila, culture, and national education goals, namely: 1 . religious, 2 . to be honest, 3. tolerance, 4. discipline, 5. work hard, 6. Creative, 7. independent, 8. democratic 9. curiosity, 10. the spirit of nationality, 11. Love of country, 12. rewarding achievement, 13 . friendly / communicative, 14 . love peace, 15 . joy of reading, 16. the environment concern 17 . social care, and 18. Responsibilities (Depdiknas, 2006).

For those who often have the receiver position information, the students would have the curiosity tend to be large so as to make them actively update the information and then share it. Information processing theory to analyze how students manipulate information, monitor, and create strategies to deal with and share. Processing incoming information requires selective attention to events, objects, symbols, and certain other stimuli for this information to be learned. Another study by Kulhavy RW, et al. that the "attention" of the students 
could be described as "front-line manager" that are important in determining the information to be provided for further processing (Kulhavy, 1986).

\section{b. Disclosure of public information}

Based on the cybernetics, which is considered a theory permeating all scientific disciplines, the concept of information is spreading into many other disciplines. For example, cognitive psychology and science adopt it, and they understand the information as a psycho-physiological phenomenon and process under way in human consciousness. Information determined (informs) the knowing subject (Stodola, 2019). No wonder that experts grapple with definitions of information, and that their definitions are often very different from each other. It is often indicated in various knowledge contests, that it is difficult to explain especially the words we meet today and every day. This is because these words become so common to us that we are no longer even think about what it means. At the same time, to find out the meaning of our words absolute use is necessary and that is the first step to dispel many misunderstandings.

Now let's focus on choosing an interesting definition itself. We can divide it into three groups. The first group contains writers who understand information as something objective and not considering human subjects. The second group includes writers for whom human subjects an inherent part of the information process; information especially on the subject. The third group consists from writers who, while they do not deny the role of the human subject, but look at the information on part of the record of human knowledge through the sign system, both identify directly withthis note or by its meaning (Stodola, 2019).

Everyone has the right to communicate and obtain information to develop personal and social environment, and the right to seek, obtain, possess, store, process and convey information by using all available channels. As a commitment to human rights with the right to public information, Article 28 of the Constitution $45 \mathrm{~F}$ asserts (Kemkes, 2016). Everyone has the right to communicate and obtain information to develop personal and social environment, and the right to seek, obtain, possess, store, process and convey information by using all available channels.

In the setting at Article 2 of Law Public and set about the organization of public information (LBHM, 2016): Basically, public information is open and accessible to any user information, except for confidential information as provided by law, decency and common interests are based on examinations of 
the consequences if the information given to the public and after consideration by consideration to protect the larger interests.

Each public information should be obtained by each applicant's public information quickly, timely, low cost, and simple way. As is public information is based on Article 1 paragraph 2 Law on Public Information, the information generated, stored, managed, delivered and / or received by a public body relating to the conduct and administration of the state and / or organizers and the holding of public bodies more in accordance with this law, as well as other information that is also related to the public interest (LBHM, 2016).

Pursuant to article 1 paragraph 1 of Law Public Disclosure: is the information is information, statements, ideas, and signs containing the value, meaning and messages, data, facts, and explanations that can be seen, heard, and read the served in a variety of packaging and format in accordance with the development of information technology and electronic communications or non-electronic (LBHM, 2016). Under the provisions of Article 2 mentioned above, the nature of the information that must be provided and published is the Maximum Access Limited Exemption, namely the widest access to public information with the exception of strict and limited.

Under the terms of Article 17 of UU KIP is set a few exceptions the information, the information is exempt, among others (LBHM, 2016): 1. each public agency shall provide access to any applicant to obtain public information to get Public Information; 2. that can interfere with the protection of intellectual property rights and protection from unfair competition; 3 . what could endanger state security and defense; 4 . who can reveal the natural wealth of Indonesia; 5. what can be detrimental to national economic resilience; 6 . what can be detrimental to the interests of foreign relations; 7 . the authentic act can reveal the contents of a personal nature and one's will or the whim last; 8. what can reveal personal secrets; 9. memorandum or letters intra between public agencies or public bodies, which by their nature are confidential unless the decision of the Information Commission or the courts; 10. the information shall not be disclosed by law to be public information openness is an obligation of every public body which includes the executive, judicial, legislative, and other state officials who receive funds from the State Budget (APBN) or Budget Revenues and Expenditure (budget), and including also that nongovernmental organizations, whether incorporated or unincorporated, such as non-governmental organizations, associations, and other organizations that 
manage or use the funds which partly or wholly sourced from the state budget or the budget, community contributions, and /or abroad.

\section{c. Social Media}

As we know social media is not a formal communication channel, so the issues raised still require formal notification through traditional means (such as written letters, face-to-face contact, and telephone conversations) before any action. One might argue that information shared through this channel is often unclear and, sometimes considered inaccurate. To avoid misinformation and misdirection, these organizations usually assess the credibility or authenticity of information through traditional means. However, it can be said that the involvement of social media gives a human element to conversations with the public. This helps public organizations not be seen as tone deaf or insensitive to public concerns and needs. social media space presents two challenges: (1) an excess of information that constantly requires organization and (2) a lack of quality assurance of content, which requires constant monitoring of the credibility of public organizations. These policies and strategies enable the handling of freedom to utilize social media under a controlled and measurable environment, where relevant and valuable ideas are shared about how to approach various organizational and community problems (Anthony, 2020). Igwe and Ononye (2020) stated the use of social media and its effects on knowledge sharing. The use of social media has a significant effect on sharing inside and outside knowledge.

Henry said that research shows that four out of 10 Indonesians are active in social media. Most people cannot live more than seven minutes without a cell phone. Internet access is an average of eight hours a day. Furthermore, as vital as internet access, specifically social media, this can be used by people as a means to an end, both positive and negative (Devega, 2017). Various posts on social media can make people provoked by cyberspace activities even though the voices are only Hoaxes, Hate Speech, Provocation and so on. So that people are asked to be careful in understanding the use of social media. Spreading bad things can be a digital trail for us.

Niken said that the need for a social media literacy process to all levels of society, both students and the general public, so that the social media we use is much healthier with positive content that brings benefits not only for ourselves but also for the community and more than that useful for the nation 
and state. The internet is like a double-edged knife, because it allows people to communicate and interact quickly, but on the other hand social media also has a negative impact to spread hoax information, hate speech, distortion of facts, and provocation (Devega, 2017). Therefore, our society needs to be equipped with qualified literacy skills and educated to ward off information that is incorrect and may not be disseminated. The public needs to be equipped with a penchant for disseminating positive things. This we can instill in the character of our young generation.

The development of the media is so rapid, in fact it has facilitated communication in conveying information, so as to save time and money. Through community social media are given freedom of expression to issue opinions. However, the misuse of social media in spreading information also impacts the number of users entering the legal sphere as a result of spreading information on social media that does not use ethics. Kadiskominfo Gianyar conveyed how good we are always ethical in using social networks, and must be smart to take advantage of social media. interaction on social media is very broad. So once entered into social media the whole world will know participatively from the diverse participants and relatively free communication (Dina, 2017).

\section{Methods}

This research was conducted by survey method. The population in this study are all classes in nursing and pharmacy classes at Vocational Health School of Sadewa, Yogyakarta. The sampling technique used proportionate stratified random sampling to obtain samples of two classes include a class of nursing and a pharmaceutical. Technique of data retrieval is done by distributing questionnaires with the Likert scale to participants in the nurisng and pharmaceutical classes. Questionnaires for this survey previously validated by a communications lecturer at the Islamic University of Indonesia, in Yogyakarta. Items on the questionnaire are contained 15 questions covering 8 items curiosity of students to information and 7 items are their sense of responsibility to the information obtained. Using data Analysis is to highlight how great score on an item of curiosity and responsibility for the information. In addition, the calculation of the percentage of the overall score achieved with maximum ideal score. 


\section{Results and Discussion}

Research with information checking as a form of character management in education aims to determine the level of curiosity and responsibility of society in this case young people to information, so as to see how they manage the information obtained and disseminated. It is undeniable that social media gives the widest possible space to the public, users of social media can easily express their opinions. This needs to be monitored because the information circulating on social media can cause the mindset of readers to be affected so it needs to be verified.

In this study tracing how far the curiosity of students' pesetrta indicated by several questions such as how often students look for the latest information in daily life, whether they always follow the latest information circulating, whether to pay attention to the source of information, and the author before reading the information, whether the information received can add their insights, and whether they apply selectivity to the information received.

Whereas in the realm of the responsibilities of this study try to explore the extent to which students read in full the contents of the information, check the sources of information obtained, consider from various sources before sharing information, compare information you get with other information, present the discussion process before sharing, checking correctness of information obtained or confirm if it turns out the information obtained is wrong.

Curiosity and responsibility in the management of character education in the information circle can be grouped in several sections such as the table below:

Table 1: Scope of curiosity and responsibility

\begin{tabular}{cll}
\hline No & \multicolumn{1}{c}{ Curiosity } & \multicolumn{1}{c}{ Responsibility } \\
\hline 1 & Enthusiastic looking for information & Read holistically \\
\hline 2 & $\begin{array}{l}\text { Pay attention to the contents of } \\
\text { information }\end{array}$ & Check source \\
\hline 3 & Read information sources and authors & Discussion \\
\hline 4 & Think about the impact of information & Check the truth \\
\hline
\end{tabular}

The power of information technology in this era of globalization enables the dissemination of information that is incredible. The dynamics of information 
dissemination is not rare to find many transgressors, as news spread of hoaxes in various media. Researchers try to look at the field by surveying the extent of students curiosity and responsibility on the information around them. Based on the obtained data sample surveyed scored as follows:

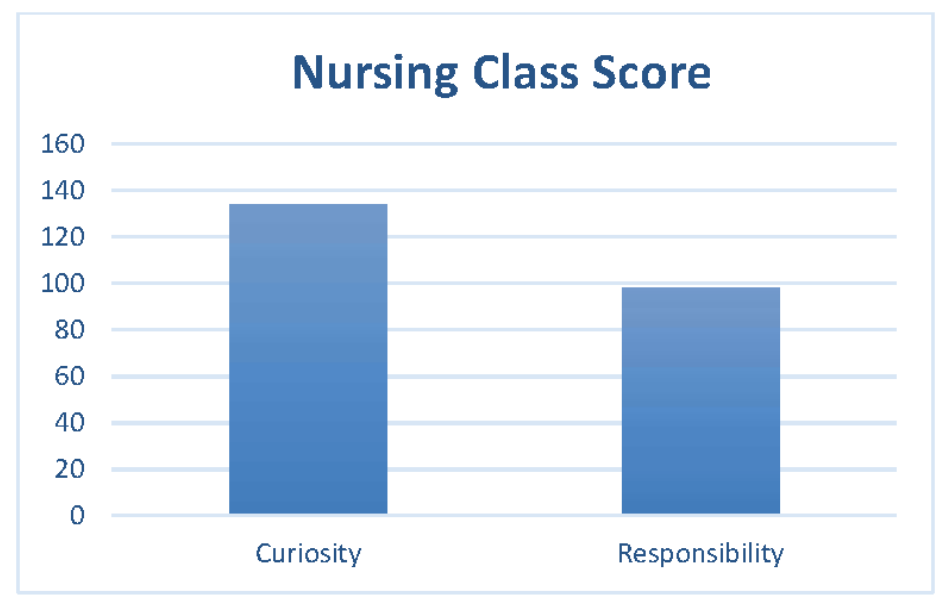

Figure 1. Score achievement diagram of nursing class.

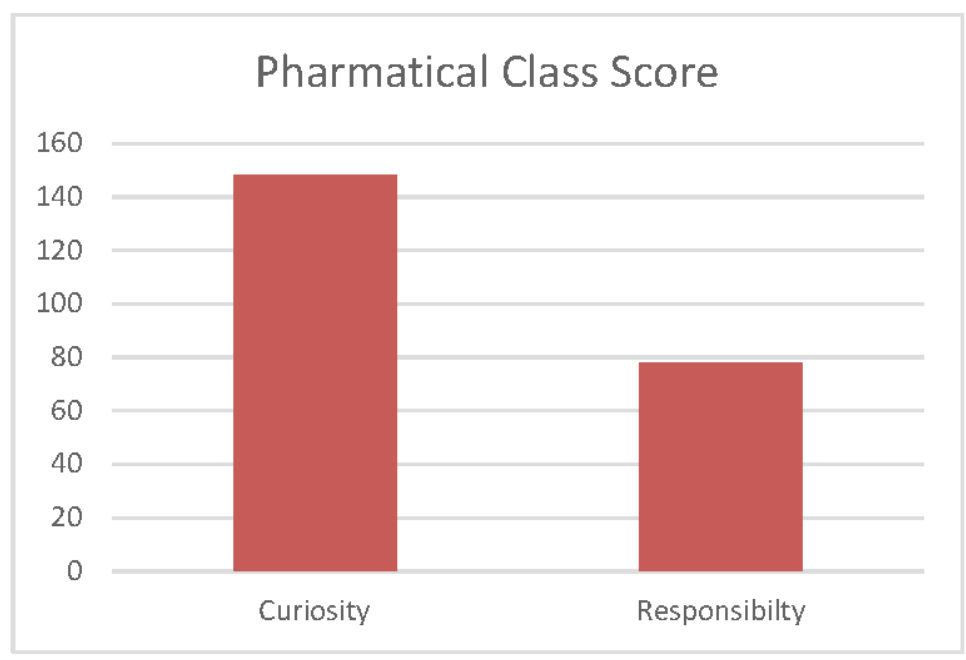

Figure 2. Score achievement diagram of pharmaceutical class.

In the both tables show that there are a nursing class score is 134 from curiosity and 98 from responsibility, so that the overall score achieved in this class of 232. While for pharmaceutical class score is 148 from curiosity and 178 
from responsibility, so the score achieved overall at 226. Based on this data it is clear that the item of curiosity is greater than items responsibility for the information.If we look at the ideal maximum score of 15 items that exist in 23 students in the respective class obtained the maximum score of 345 , making it ideal to use the maximum score can be seen the percentage of the total score of each class. Based on the data and calculations to be obtained percentage of nursing class is $65.5 \%$ and amounted to $67.25 \%$ from pharmaceutical class.

Values are still far from the ideal score is certainly a concern for us, especially who are in education to focus on character building education in the field of checking the information obtained so that culture for this information we cultivate for students as early as possible. Because after all, despite the freedom of access to information is a right, but at the same time we are bound by the rules and norms in our country, the sense of students responsibility so the news spread hoaxes do not flourish in this beloved country. Readiness of students to receive information early on with a correct and responsible manner must be instilled as valuable character education because the impact of information is the influence on mindset and mindset will certainly determine the life of a nation.

Checking information is very important for the management of our students' character, especially information obtained from social media. Social media includes a variety of technology applications that allow users to create, manage and share content, post comments and engage in discussions anywhere in the world in real time. It has many options and facilities on the same channel for users, such as sending text messages, sharing images, audio and video sharing, fast publishing, connecting with the rest of the world and with other social media applications. People use various social networking sites and are members of sites that he considers current trends and styles. Young adults especially students have embraced social media very quickly. Rafi et al. (2019) highlight the positive and negative aspects of social media on students' reading habits. The positive effect is the use of social media to increase socialization that facilitates students in their studies and they find information on social media that can be accessed and used. However, the negative aspect is that students are disturbed by the use of social media during their studies. The positive effect will be achieved if we instill of character information on students.

Information that is checked by the recipients is proof that they have implemented information literacy. Information checking literacy needs to be suggested for our educational curriculum. Stebbing et al. (2018) in their research 
stated that academics support a broader view of information literacy. Further work is needed to provide preparation for information literacy demands in the workplace including awareness of the role of informal networks in information exchange. An area that must be developed by the library team is ensuring our graduates have information literacy for work and life. At their institution, the publication of new educational and work strategies, provides opportunities in the curriculum for the development of a variety of information literacy skills related to academia, work and life.

\section{Conclusion}

The numbers are in the middle level of the ideals to be achieved above still short of the expectations. This character would need special attention to education in particular. Provision of good literacy such a piece of checking information is necessary for forming the name of the young generation.

\section{Acknowledgement}

Thank for Vocational Health School of Sadewa Yogyakarta as the place of this research and for Beasiswa Unggulan Kementerian Pendidikan dan Kebudayaan for a scholarship opportunity in our posgraduate program.

\section{REFERENCES}

Anthony, F. (2020). Social media use and its effect on knowledge sharing: evidence from public organisations in delta state, nigeria. Interdisciplinary Journal of Information, Knowledge, and Management. 15. 25-27. https://doi. org/ $10.28945 / 4503$

Chairiyah. (2011). Keefektifan metode membaca kritera untuk pendidikan karakter terintegrasi dalam pembelajaran IPS di Sekolah Dasar. Yogyakarta: PPS UNY.

Darmiyati, Z. (2012). Panduan implementasi pendidikan karakter. Yogyakarta: Universitas Negeri Yogyakarta.

Devega, E. (2017, October 9). Gunakan medsos untuk kebaikan, https://kominfo. go.id/content/detail/10846/use-medsos-for-kebaik/0/sorotan_media, Accessed 7 May 2020.

Devega, E. (2017, October 11). Literasi masyarakat kunci penggunaan media sosial sehat, https://www.kominfo.go.id/content/detail/10880/literasi- 
Information checking as a form of character management in education (Zulfah Zulfah, Rizka Amalia Shofa)

masyarakat-kuncan-use-media-social-sehat/0/sorotan_media, Accessed 7 May 2020.

Dina, S. (2017, October 8). Cerdas memanfaatkan medsos. https://kominfo. go.id/content/detail/11832/cerdas-\%20 utilized-medsos/0/sorotan_ media, Accessed 7 May 2020.

Gulo, D. (1982). Kamus psikologi. Bandung: Tonis.

Igwe, A., \& Ononye, U. H. (2020). Social media use and its effect on knowledge sharing: evidence from public organisations in Delta State, Nigeria. Interdisciplinary Journal of Information, Knowledge, and Management. 15. 25. 37. https://doi.org/10.28945/4503

Kamisa. (1997). Kamus lengkap bahasa Indonesia. Surabaya: Kartika.

Kemendiknas. (2010). Pembinaan pendidikan karakter di Sekolah Menengah Pertama. Dir. Pembinaan SMP/A Ditjen Mandikdasmen Kemendiknas.

Kulhavy, R.W., Schwarts N.H., and Petersen, S. (1986) Working memory: The encoding process. In Andre, T., \& Phye, G. (Eds). Instructional cognition. New York: Academic Press.

Noviandari, L. (2015). Statistik pengguna internet dan media sosial terbaru 2015, https://id.techinasia.com/talk/statistik-pengguna-internet-dan-mediasosial-terbaru-2015, Accessed 7 May 2020.

Poerwanti, E. (2011). Pengembangan insrtrumen Asesmen pendidikan karakter di taman kanak-kanak. PPS UNY.

Pusat Kurikulum Depdiknas. (2016). Struktur dan muatan kurikulum. Depdiknas.

Putri, R. (2017). Penyebaran berita bohong dan pilkada serentak 2017," http:// www.rappler.com/indonesia/opini/153532-penyebaran-berita-bohongpilkada-2017, Accessed 7 May 2020.

Rafi, M., Asim, A., Khan, M.T., Arif, M. (2019). The effects of social media on reading habits. Pakistan Journal of Information Management $\mathcal{E}$ Libraries. 21. 46-65.

Stebbing, D., Shelley, J., Warnes, M. and McMaster, C. (2018). What academics really think about information literacy. Journal of Information Literacy. 13(1). 21-44. http://dx.doi.org/10.11645/13.1.2338

Stodola, J.T. (2019). The scope of the concept of information and the future of information science. Journal of Information and Organizational Sciences. 43 (1). 73-98. https://doi.org/10.31341/jios.43.1.5

Undang-Undang Dasar Republik Indonesia 1945, www.itjen.kemkes.go.id/ 
Journal of Social Studies (JSS), Volume 15, Number 1, 2019: 63-76

peruuan/download/1, , Accessed 7 May 2020.

Undang-Undang Keterbukaan Informasi Publik, http://lbhmasyarakat.org/wpcontent/uploads/2016/04/Buku-Saku-Mengenal-UU-KeterbukaanInformasi-Publik.pdf, Accessed 7 May 2020.

Zuhdi, D. (2008). Pendidikan humanism. Jakarta: Bumi Aksara. 